\title{
Characterization of the Lipid Components in Desmodesmus and Scenedesmus Strains: Lipid Content, Lipid Classes and Fatty Acid Profile
}

\author{
Carolina Vieira Viegas ${ }^{1}$, Gisel Chenard Díaz ${ }^{1 *}$, Yordanka Reyes Cruz¹, \\ Leonardo Brantes Bacellar Mendes ${ }^{2}$ \\ ${ }^{1}$ GREETEC Laboratory, Federal University of Rio de Janeiro (UFRJ), Rio de Janeiro, Brazil \\ ${ }^{2}$ CENPES/PETROBRAS-Leopoldo Américo Miguez de Mello Research Center, Rio de Janeiro, Brazil \\ Email: *yordankabiodiesel@yahoo.com.br
}

How to cite this paper: Viegas, C.V., Díaz, G.C., Cruz, Y.R. and Mendes, L.B.B. (2020) Characterization of the Lipid Components in Desmodesmus and Scenedesmus Strains: Lipid Content, Lipid Classes and Fatty Acid Profile. American Journal of Plant Sciences, 11, 2103-2121.

https://doi.org/10.4236/ajps.2020.1112148

Received: October 30, 2020

Accepted: December 21, 2020

Published: December 24, 2020

Copyright $\odot 2020$ by author(s) and Scientific Research Publishing Inc. This work is licensed under the Creative Commons Attribution International License (CC BY 4.0).

http://creativecommons.org/licenses/by/4.0/

(c) (i) Open Access

\begin{abstract}
The lipid composition in terms of the amount of neutral lipids, free fatty acids and polar lipid content is of great importance to make full use possible of this fraction and to define the suitability of its application, either as a raw material for fuel production, nutraceutical purposes or feed. In addition to the fatty components present in the lipid extract, other components may be included, such as: carotenoids, pigments and sterols. The microalgae studied in this work, Scenedesmus sp. and Desmodesmus sp., were subjected to the same growth conditions and evaluated for lipid content, quantification and diversity of lipid components as well as its fatty acid profile. For lipid determination two extraction methods were compared: the J: Schmid-BondzynskiRatzlaff and Bligh \& Dyer method. For Desmodesmus sp. $5.43 \% \pm 0.41 \%$ and $9.18 \% \pm 0.33 \%$ of lipids were obtained on an ash-free dry weight basis and for Scenedesmus sp. $12.46 \% \pm 0.38 \%$ and $8.16 \% \pm 0.42 \%$ of lipids were obtained on ash-free dry weight basis using for both methods J: Schmid-BondzynskiRatzlaff and Bligh \& Dyer, respectively. For the identification of the main lipid components present in the extracts, the Thin layer chromatography (TLC) technique was used. This made it possible, using a simple and inexpensive method, to identify the compounds extracted by different extraction methods, that is, it was possible to verify the selectivity of the different extraction methods. In addition, it has been shown that using these methods, widely described in the literature as methods of extracting lipids in practice, extracts a wide diversity of compounds. The major lipid class for both microalgae was fatty acids with amounts between $23.62 \%-38.02 \%$. The triglycerides percentage in biomasses without chemical treatment did not exceed $18.26 \%$. In the lipid extract obtained with Bligh \& Dyer, the microalgae Desmodesmus sp.
\end{abstract}


presented $55.26 \%$ of unsaponifiable material, higher than the amount present using the same extraction method for Scenedesmus sp. 49.06\%. Among the main unsaponifiables identified are hydrocarbons (carotenes) and sterols esters. The acid treatment of biomass, method J: Schmid-Bondzynski-Ratzlaff, showed selectivity of $72.84 \%$ and $76.66 \%$ for obtaining fatty material from the microalgae Desmodesmus sp. and Scenedesmus sp., respectively. The results showed that depending on the method used for extraction, the lipid fraction will be different in relation to the percentage of fatty components.

\section{Keywords}

Microalgae, Desmodesmus sp., Scenedesmus sp.

\section{Introduction}

The term "biomass" means any organic matter that is available on a recurring or renewable basis including, plants, agricultural waste, aquatic plants, wood and wood waste, animal waste, municipal waste and other waste used for industrial energy production, fuels, chemicals and materials [1] [2] [3].

An emerging alternative is the use of aquatic biomass, it is estimated that the global primary production of biomass is $50 \%$ aquatic and $50 \%$ terrestrial. To this day, government policies have focused almost exclusively on the use of terrestrial biomass, paying little attention to aquatic crops, taking as examples macro and microalgae. Microalgae are prokaryotic or eukaryotic photosynthetic microorganisms that can grow quickly due to their ability to convert $\mathrm{CO}_{2}$ and transform them into proteins, carbohydrates and lipids [3] [4] [5].

Microalgae are important primary producers in aquatic environments and have been used in aquaculture, animal feed, as a source of carotenoids, phycobiliproteins, polyunsaturated fatty acids, functional foods and biofuels and other biomolecules explored for commercial use [1] [6] [7]. The lipids obtained from microalgae have attracted attention from researchers due to the possibility of conversion to biofuels, mainly biodiesel and green diesel [8] [9]. The development of an effective technique in the process of extracting lipids on a large scale from microalgae biomass is still a challenge for researchers [10] [11]. The factors that influence this process are not yet completely known and no method has been established for extraction on an industrial scale. Currently, it is believed that the extraction process represents an important limitation for the use of microalgae lipids as fuels. The selection of a solvent system must, therefore, take into account its chemical affinity with the classes of lipids to be extracted. In microalgae, the lipid fraction may undergo changes in its composition according to the polarity of the solvent used for its extraction [11]. The addition of a polar and a nonpolar organic solvent facilitates the extraction of neutral lipids associated with the membrane. Microalgae have a resistant cell wall, which is a major barrier to the extraction processes and the procedure for breaking the cell wall is 
an important operation to obtain the compounds of interest. The cell wall plays an important role in the extraction process, for example, the presence of the cell wall can prevent direct contact between the solvent and the cell membrane and hinder extraction [12]. The microalgae cell wall provides the cells with rigidity and resistance, offering protection against mechanical stress [13] [14]. Some cell disruption techniques have been used to improve extraction efficiency, such as: the chemical treatment of biomass [14] [15].

In addition to the fatty acids present in the lipid extracts in the extraction process, it also inevitably leads to the co-extraction of components with affinity to the solvent that can lead to overestimated values on the amount of fat content present in the microalgae [16]. These non-fatty components are mainly carotenoids, phytosterols and their derivatives (vitamin E), in addition to some minor components such as chlorophyll, polyphenols, hydrocarbons and terpenic alcohols. Unsaponifiables are noble ingredients for the chemical and pharmaceutical industry due to recent discoveries of their numerous health benefits [17] [18].

From the reviews found in the literature, knowledge of the quality of the extract obtained after extraction must be assessed [19]. Due to the great variability between the types of microalgae species, it is generally difficult to compare the results obtained in other studies, because with each change in the cultivation conditions of these microorganisms it leads to a variation in the accumulated compounds. Therefore, in this research, aiming at the extraction of fatty components accumulated in Desmodesmus sp. and Scenedesmus sp. grown in raceway photobioreactors, the amount of lipids extracted by the Bligh \& Dyer method (without acid hydrolysis) and J: Schmid-Bondzynski-Ratzlaff (acid hydrolysis) was determined. The extracts were evaluated for the quality of each fraction, via thin layer chromatography, to identify the main components [20] [21] [22]. Method simple and inexpensive allows identifying the compounds extracted by different extraction methods, to verify the selectivity of the different extraction methods. In addition, the use of these methods, widely described in the literature as methods of extracting lipids in practice extract a wide diversity of compounds.

The main contribution of this study is to define what types of compounds can be extracted by each method to be used depending on the application. As well as gas chromatography-FID identification of the main fatty acids present in these extracts. From this study it was possible to evaluate which microalgae had the highest lipid content accumulation under the same culture conditions as well as which method was more selective for obtaining fatty material [23].

\section{Materials and Methods}

The biomass of Scenedesmus sp. and Desmodesmus sp., provided by UFRN (Federal University of Rio Grande do Norte), was grown for 5 days in an open pond with a volume of 20.000 L. Growth monitoring was performed by optical density, as described by Lee and Aaron [16] [24], making absorbance readings at wavelengths of $680 \mathrm{~nm}$ and $750 \mathrm{~nm}$ daily. At harvest, the cultivation was trans- 
ferred to a settling tank and flocculated until biomass reached approximate concentration of $10 \mathrm{~g} \cdot \mathrm{L}^{-1}$. The biomass was removed with $85 \%$ humidity for one form and later dried in an oven for 24 hours at $80^{\circ} \mathrm{C}$.

\subsection{Extraction Method-Bligh \& Dyer}

Extractions were performed in a $50 \mathrm{~mL}$ flask, starting from $5 \mathrm{~g}$ of dry biomass with $15 \mathrm{~mL}$ of the mixture chloroform: methanol $(2: 1 \mathrm{v} / \mathrm{v})$, following the methodology described in the literature [25] [26] [27] [28] [29]. A solvent: charge ratio of 3:1 ( $\mathrm{mL}$ of solvent: $\mathrm{g}$ of biomass), extraction time of 2 hours at a temperature of $60^{\circ} \mathrm{C}$ and $200 \mathrm{rpm}$ stirring on a magnetic stirrer were used. For the separation of residual biomass from the liquid phase (lipid fraction + solvent), a filter paper filtering process was carried out. Then the biomass was washed with $30 \mathrm{~mL}$ of the solvent mixture selected for the extraction step and filtered again. The solvents were removed from the liquid phase by vacuum evaporation and the lipid fraction (not volatile under operating conditions) was dried to constant weight in an oven at $60^{\circ} \mathrm{C}$. The experiments were carried out in triplicates and the extraction yield was determined in percentage, in relation to the dry biomass mass. The lipid extracts were analyzed by Thin Layer Chromatography (TLC) and compared with the available lipid standards.

\subsection{Extraction Method-Acid Treatment- J: Schmid-Bondzynski-Ratzlaff}

The extraction was performed starting from $5 \mathrm{~g}$ dry biomass-in a $50 \mathrm{~mL}-10$ $\mathrm{mL} \mathrm{HCl} 8 \mathrm{M}$ falcon tube; Hydrolysis: 10 minutes water bath at $60^{\circ} \mathrm{C} ; 1^{\text {st }}$ Extraction: $10 \mathrm{~mL}$ absolute ethanol; $25 \mathrm{~mL}$ ethyl ether; $25 \mathrm{~mL}$ petroleum ether; Separation of the phases in a funnel. $2^{\text {nd }}$ and $3^{\text {rd }}$ Extraction: $10 \mathrm{~mL}$ absolute ethanol; 25 $\mathrm{mL}$ ethyl ether; $25 \mathrm{~mL}$ petroleum ether; Washing of the "solvent" phase with distilled water until $\mathrm{pH}$ of the water $=7$ (to remove $\mathrm{HCl}$ residues); Evaporation of the solvent; Kiln drying at $60^{\circ} \mathrm{C}$ [30]. The experiments were conducted in triplicate. The lipid extracts were analyzed by Thin layer chromatography (TLC) and compared with the available lipid standards.

\subsection{Method of Identifying Lipid Classes-Thin Layer Chromatography (TLC)}

For identification of the lipid classes of interest present in the extracts of the microalgae Scenedesmus sp., was used Thin layer chromatography (TLC). In this analysis, $0.001 \mathrm{~g}$ of the extracted lipid fraction was dissolved in $600 \mu \mathrm{L}$ of chlorofor plate $\mathrm{m}$. The equivalent of $0.03 \mu \mathrm{L}$ of the solution was applied to a $60 \mathrm{TLC}$ (Merck) silica gel with the aid of an automatic pipette. In addition to the sample to be analyzed, equal amounts of triolein, diolein, monoolein, fatty acid, ergosterol and cholesteryl oleate were applied to the plates for comparison and quantification. To ensure efficient separation and obtain acute bands of nonpolar lipids, the separation was performed as described below. First, the solvent mixture composed of petroleum ether/diethyl ether/acetic acid (70:30:2 v/v) was used to 
separate the lipids, until reaching $2 / 3$ the height of the silica plate $(7 \mathrm{~cm})$. After drying the plate, the separation continues in the same direction using the solvent mixture composed of petroleum ether/diethyl ether (100:2 v/v) until it reaches the top of the plate $(9 \mathrm{~cm})$ (Figure 1) [21].

The chromatographic plate after elution was revealed with iodine vapor and the stain retention (Rf) factor of the standards and sample components was determined.

To achieve an irreversible staining of nonpolar lipids and sterols in the TLC plate, it was kept in a solution of $0.63 \mathrm{~g}$ of $\mathrm{MnCl}_{2} \cdot 4 \mathrm{H}_{2} \mathrm{O}, 60 \mathrm{~mL}$ of water, $60 \mathrm{~mL}$ of methanol and $4 \mathrm{~mL}$ of sulfuric acid for 10 seconds, followed by heating to $105^{\circ} \mathrm{C}$. The intensity of the color depends on the heating time, which must be a minimum of $30 \mathrm{~min}$. With the aid of the Image Master Total Lab version 1.11 program, was used to identify and quantify the lipid classes present in the extracts. The methodology previously described was used to identify the lipid classes present in the extracts obtained by the different extraction methods evaluated in this work. The main objective of this analysis was to assist in the selection of the procedure that allows a more selective extraction of lipids convertible into biodiesel.

\section{Results and Discussion}

\subsection{Effect of the Extraction Method on Lipid Recovery}

The microalgae Desmodesmus sp. and Scenedesmus sp. were evaluated for lipid accumulation capacity under the same cultivation conditions. The average values obtained in the extraction of lipids, following the different methods, are shown in Figure 2 and were expressed as a percentage in relation to the ash-free dry weight biomass.

It is observed that the lipid yields showed statistically significant differences ( $\mathrm{p}$ $<0.05$ ). According to the literature, as expected, the extraction method directly influences the content of recovered lipids [3] [31] [32] [33]. In the microalgae Desmodesmus sp. the recovery of lipids using the Bligh-Dyer method was $9.18 \%$ $\pm 0.33 \%$ slightly higher than that obtained for the microalgae Scenedesmus sp.

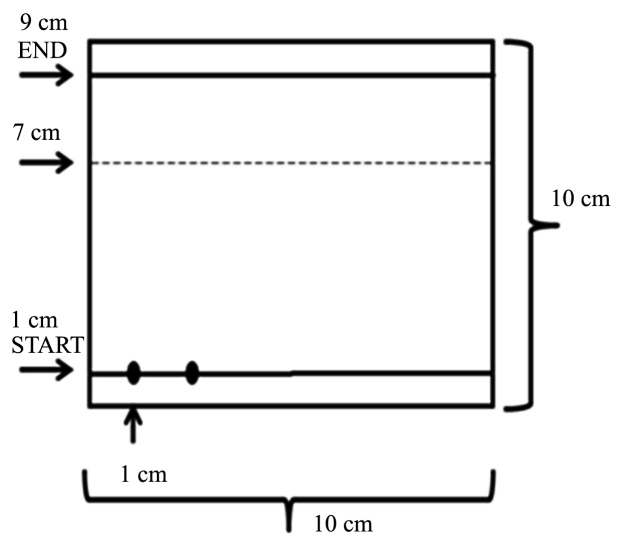

Figure 1. Example of marking the plate TLC $10 \times 10 \mathrm{~cm}$. 


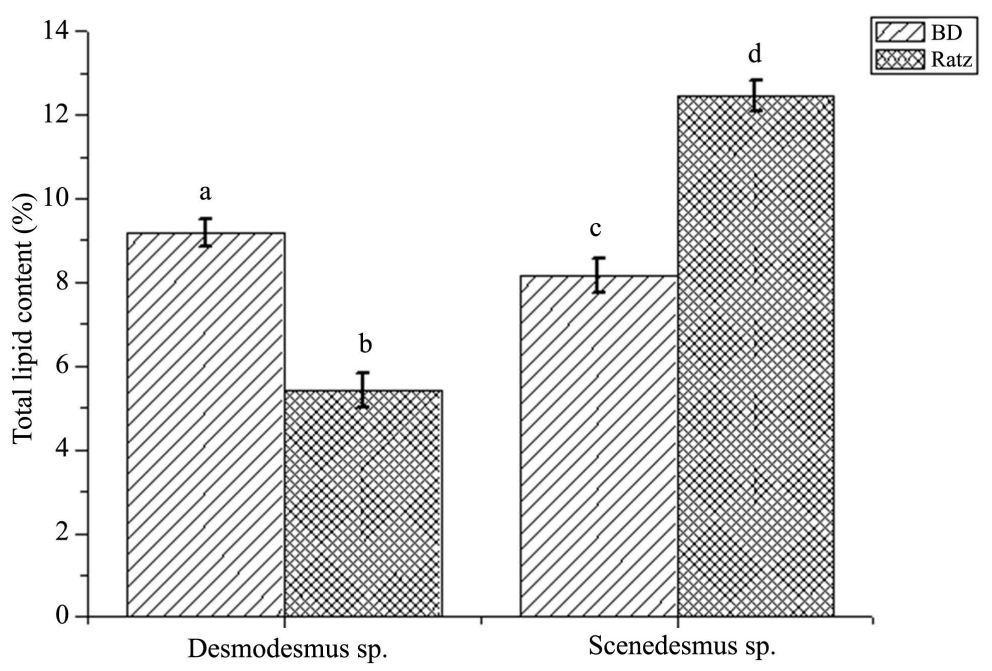

Figure 2. Lipid content ${ }^{\star}$ obtained by the methods of Bligh \& Dyer (BD) and J: Schmid-Bondzynski-Ratzlaff (Ratz) from dry, ash-free biomass. ${ }^{\star}$ Values calculated based on triplicates of experiments. Different letters differ statistically from each other.

$(8.16 \pm 0.42)$. The recovery of lipids for the microalgae Scenedesmus sp. using the method J: Schmid-Bondzynski-Ratzlaff was $12.46 \% \pm 0.38 \%$, showing that the presence of lipids in this polarity range was quite similar for both microalgae. The presence of polar solvents such as chloroform and methanol helped the extraction of lipids such as phospholipids and glycolipids, as they break these associations, forming hydrogen bonds with the polar lipids of the complex, this behavior can be partially explained due to the presence of neutral lipids inside the cell, which bind strongly to proteins located in the cell membrane, via hydrogen bonds, forming a complex with polar lipids. Van der Waals interactions between the nonpolar solvent and lipids are not able to break this membrane, based on lipid-protein associations. Polar solvents, such as methanol or ethanol, break these associations, forming hydrogen bonds with the polar lipids in the complex. In addition, the use of polar solvents such as acetone, ethanol, methanol increases the affinity for pigments, sugars, and polar lipids, leading to an increase in these compounds in the extract [34]. Therefore, the addition of a polar solvent helps the extraction of neutral lipids associated with the membrane.

\subsection{Composition of the Lipid Classes Identified in the Extracts of the Microalgae Desmodesmus sp. and Scenedesmus sp.}

To identify the lipid classes present in the extracts, a thin layer chromatography analysis of the Bligh \& Dyer and J: Schmid-Bondzynski-Ratzlaff extracts was performed (Figure 3 ). The plates show the presence of fatty acids, triglycerides, diglycerides and sterols according to the Rf (retention factor) of the added standards and the order of elution of each compound.

The chromatograms generated from Figure 3 referring to the lipid extracts of the microalgae Desmodesmus sp. and Scenedesmus sp. can be seen in Figures $4-7$. 


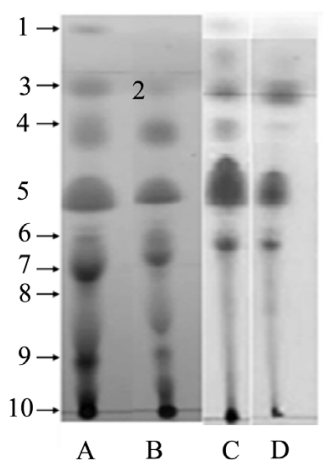

Figure 3. Separation of components present in lipid extracts by thin layer chromatography. Lines: A-Lipid extract-Bligh \& Dyer-Desmodesmus sp.; B-Lipid extract-Bligh \& Dyer-Scenedesmus sp.; C-Lipid extract-J: Schmid-Bondzynski-Ratzlaff-Desmodesmus sp.; D-Lipid extract-J: Schmid-Bondzynski-Ratzlaff-Scenedesmus sp.; Lipid Components (from top to bottom): 1-Carotenes; 2-Sterol ester; 3-Fatty ester; 4-Triolein; 5-Fatty acid; 6-Diglycerides; 7, 8 and 9-Pigments; 10-Polar compounds.

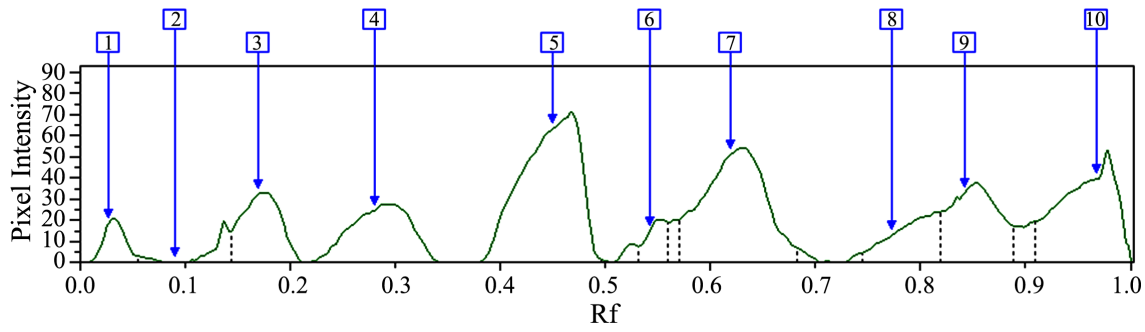

Figure 4. A-Chromatogram of the lipid extract of Bligh \& Dyer from Desmodesmus sp. Lipid Components (from top to bottom): 1-Carotenes; 2-Sterol ester; 3-Fatty ester; 4-Triolein; 5-Fatty acid; 6-Diglycerides; 7, 8 and 9-Pigments; 10-Polar compounds.

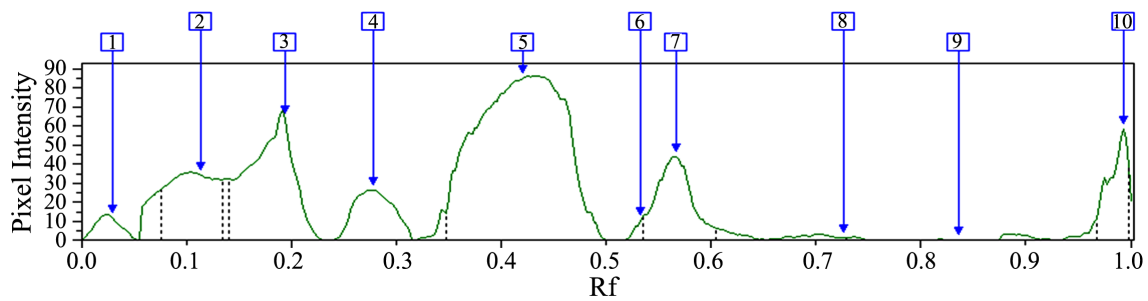

Figure 5. C-Chromatogram of the lipid extract of J: Schmid-Bondzynski-Ratzlaff from Desmodesmus sp. Lipid Components (from top to bottom): 1-Carotenes; 2-Sterol ester; 3-Fatty ester; 4-Triolein; 5-Fatty acid; 6-Diglycerides; 7, 8 and 9-Pigments; 10 - Polar compounds.

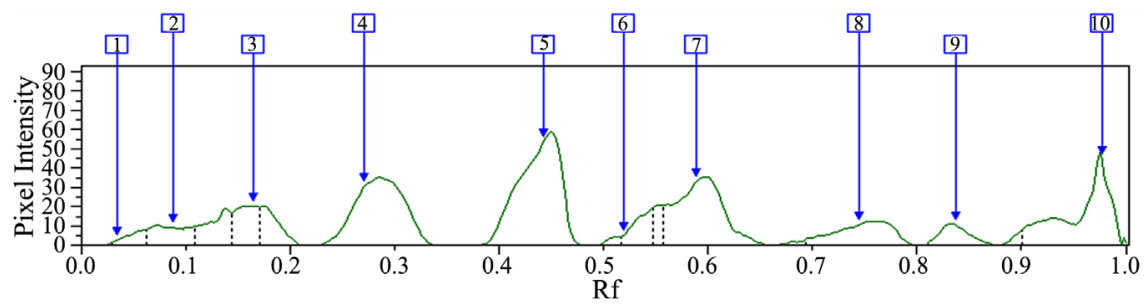

Figure 6. B-Chromatogram of the lipid extract of Bligh \& Dyer from Scenedesmus sp. Lipid Components (from top to bottom): 1-Carotenes; 2-Sterol ester; 3-Fatty ester; 4-Triolein; 5-Fatty acid; 6-Diglycerides; 7, 8 and 9-Pigments; 10-Polar compounds. 


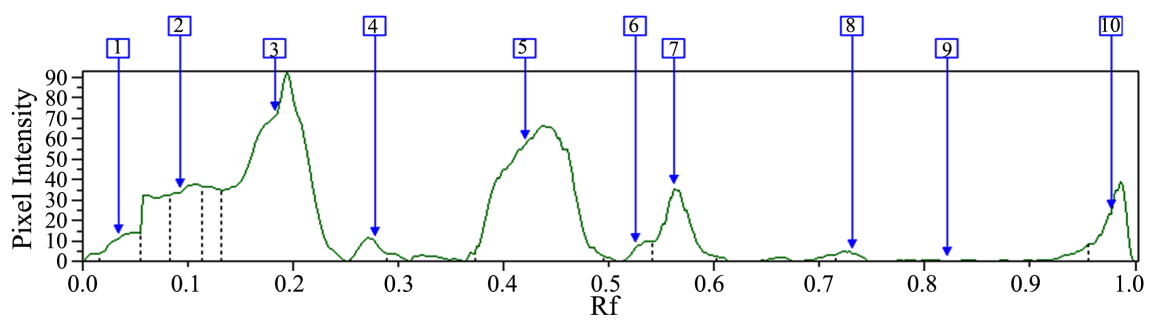

Figure 7. D-Chromatogram of the lipid extract of J: Schmid-Bondzynski-Ratzlaff from Scenedesmus sp. Lipid Components (from top to bottom): 1-Carotenes; 2-Sterol ester; 3-Fatty ester; 4-Triolein; 5-Fatty acid; 6-Diglycerides; 7, 8 and 9-Pigments; 10-Polar compounds.

According to the percentages of fatty compounds identified in thin layer chromatography (Figure 8), it is possible to observe a variation in relation to the percentage of triglycerides present in Bligh \& Dyer extracts when compared to extracts J: Schmid-Bondzynski-Ratzlaff.

The Bligh \& Dyer extract showed the highest concentration of triglycerides in the lipid fraction with $18.26 \%$ in the microalgae Scenedesmus sp. (Figure 8) and the use of this method allowed to quantify the accumulation of triglycerides in the biomass in its integral form. The microalgae evaluated in this work showed a reduced amount of triglycerides when compared to conventional oilseeds such as palm and sunflower that present amounts above 90\% [35] [36].

When we compare the levels of triglycerides obtained in this work by the microalgae Desmodesmus sp. and Scenedesmus sp. they were lower than the levels of triglycerides present in the microalgae Parietochloris incisa which presented 42.9\% and Pavlova lutheri with 40.3\% [35]. For Scenedesmus sp. according to Yao [19] the content of triglycerides did not exceed $4.1 \%$ in the lipid extract. The presence of fatty acid in the lipid extracts of the microalgae Desmodesmus sp. and Scenedesmus sp. obtained by the Bligh \& Dyer method represented 24.38\% and $24.51 \%$ respectively, in relation to the other lipid classes separated by thin layer chromatography (Figure 8). The amount of water present in the biomass after collection (85\% humidity) and the time of 24 hours, associated with a temperature of $100^{\circ} \mathrm{C}$ in the drying of the biomass, probably contributed to the oxidation of triglycerides, increasing the amount of free fatty acids. It is known that the drying temperature may have contributed to microbial degradation and consequently lipid oxidation. In addition, chlorophyll can undergo photooxidation generating $\mathrm{O}^{2-}$ radicals in the cell that can promote the degradation of lipids [37]. According to the literature, the microalgae Phaeodactylum tricornutum also showed high levels of free fatty acids, which probably resulted from lipid degradation during the storage and processing time of the biomass [38]. According to Ryckebosch [38] when storing biomass of microalgae in natura, without any type of enzymatic inactivation with a high amount of water, lipolysis occurs naturally.

At the points of origin of application of the sample under the chromatography plate, in the lipid extracts of Bligh \& Dyer of both strains evaluated in this work, 


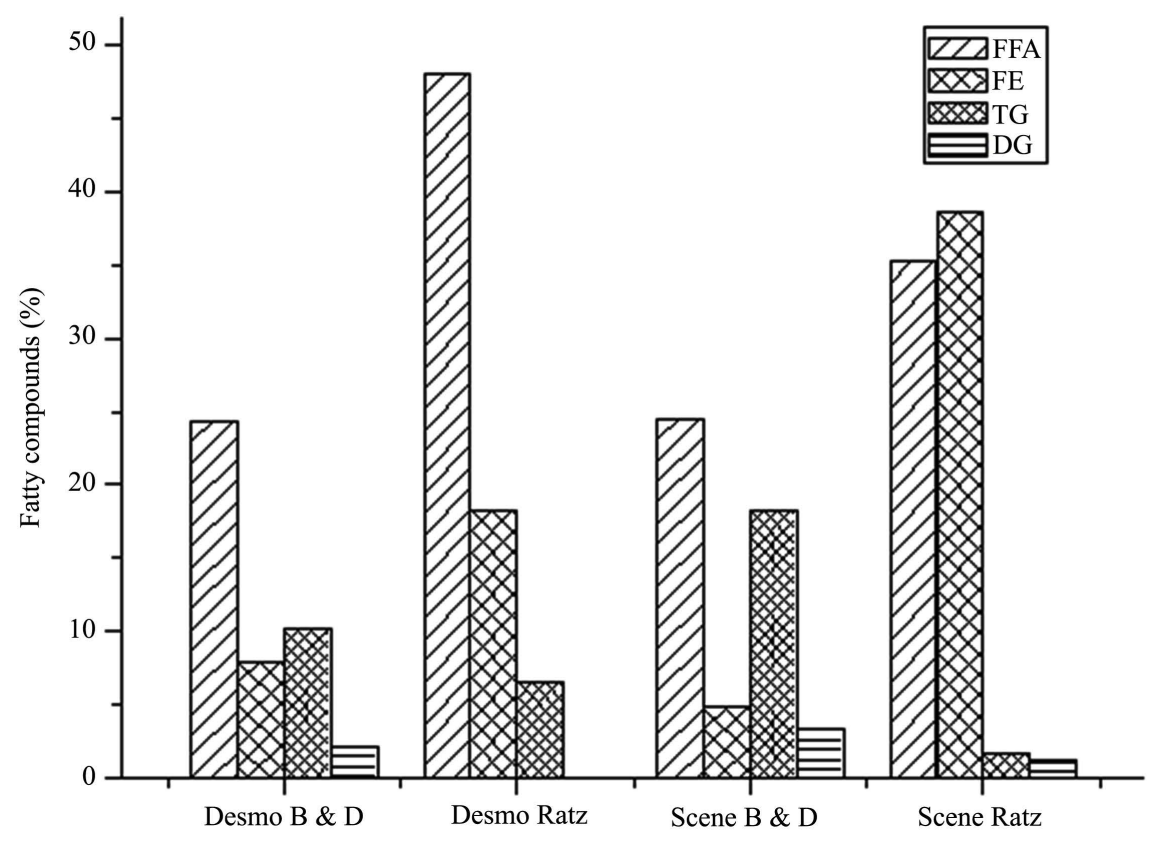

Figure 8. Fatty components present in lipid extracts. Legend: FFA: Fatty acids; FE: Fatty esters; TG: Triglycerides; DG: Diglicerides. Desmo-Desmodesmus sp.; Scene: Scenedesmus sp.; B \& D-Extraction method via Bligh \& Dyer, Ratz-Extraction method via J: Schmid-Bondzynski-Ratzlaff.

they indicated a higher concentration of polar compounds (Figure 9). These compounds retained at the base of the plate demonstrated that they did not show sufficient affinity to interact with the mobile phase composed of petroleum ether and ethyl ether, having more affinity with the stationary phase (Silica). In this case, the greater the affinity of the compounds with the stationary phase, the greater the polarity of the compounds. It was possible to evaluate that the amount of polar compounds present in the Bligh \& Dyer extracts from the microalgae Desmodesmus sp. and Scenedesmus sp. represented 15.59\% and 15.55\% of the total lipids identified. In the presence of chloroform and methanol, used in Bligh \& Dyer, a greater number of polar compounds may be extracted due to the affinity to the extracting solvents. According to Chen [39], microalgae grown in autotrophic form presented $70.6 \%$ of polar lipids, while microalgae cultivated in a heterotrophic manner, only $19 \%$ of total lipids were polar lipids. No additional separation of the polar lipids has been performed, however, according to Yao [15], the vast majority of polar lipids present in microalgae include phospholipids and glycolipids.

In the acid treatment of biomass, structures such as proteins, polysaccharides and lipids due to the presence of $\mathrm{H}_{3} \mathrm{O}^{+}$ions in water undergo hydrolysis, causing decomposition into amino acids, simple sugars and fatty acids [40] [41]. It can be seen in Figure 9 that in the extracts of J: Schmid-Bondzynski-Ratzlaff there is an increase in the amount of free fatty acids and a decrease in triglycerides and polar compounds. According to Figure 9, it was possible to observe that in the extracts of Desmodesmus sp. and Scenedesmus sp. with acid treatment, the 


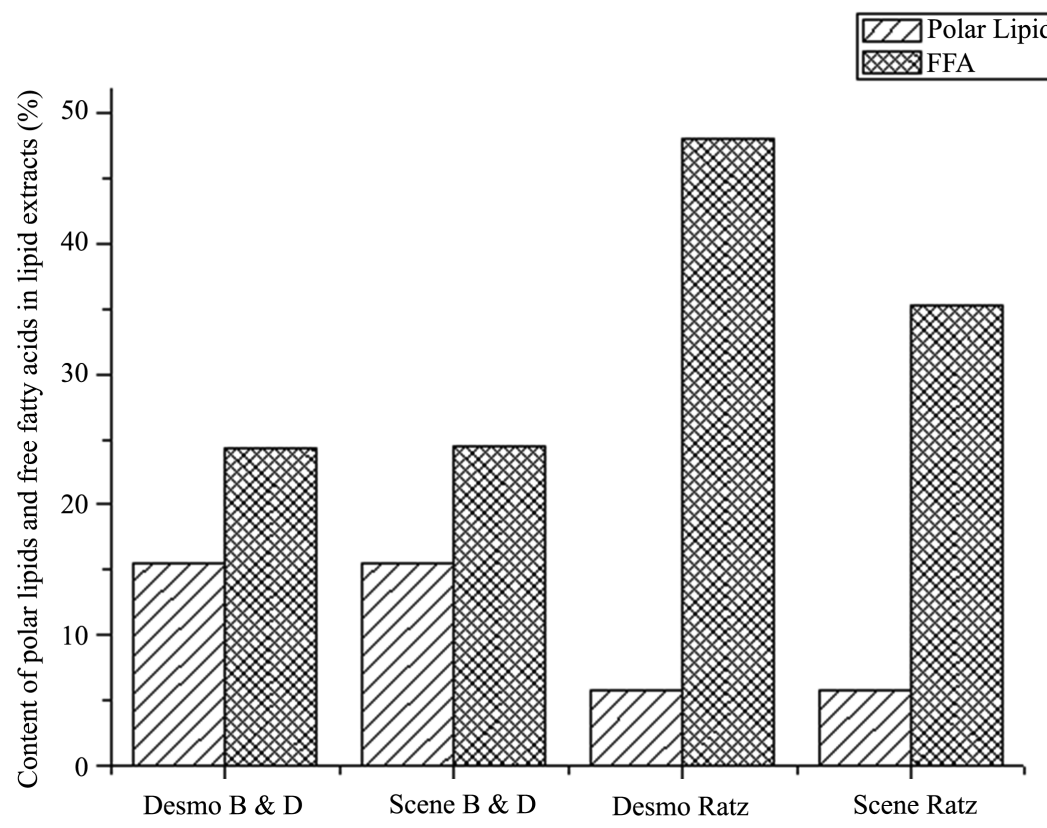

Figure 9. Content (\%) of polar components and fatty acids in lipid extracts. Legend: FFA: Free fatty acids. Desmo-Desmodesmus sp.; Scene: Scenedesmus sp.; B \& D-Extraction method via Bligh and Dyer, Ratz-Extraction method via J: Schmid-Bondzynski-Ratzlaff.

amount of polar lipids decreased to $5.76 \%$ and $5.82 \%$, respectively. The amount of triglycerides in extracts with acid treatment for the biomass of Desmodesmus sp. and Scenedesmus sp., this amount decreased to $6.52 \%$ and $1.73 \%$, respectively. The increase in the concentration of fatty acids in the extracts of $): S c h m-$ id-Bondzynski-Ratzlaff in the microalgae Desmodesmus sp. and Scenedesmus sp. of $48.03 \%$ and $35.22 \%$, respectively, was higher than that reported by Petrok [35] for Chlorella sp. of $31 \%-32 \%$ after the biomass hydrolysis. This fact can be partially explained by the presence of $\mathrm{HCl}$ used to break these bonds that keep the more complex triglycerides and lipids that are hydrolyzed to simpler lipids like free fatty acids [42]. An carbonyl, for example, from a triglyceride, undergoes an electrophilic attack from $\mathrm{H}^{+}$, forming a carbocation. This carbocation then undergoes a nucleophilic attack by a water molecule, forming a tetrahedral intermediary. Then, the elimination of a diglyceride and a fatty acid occurs, together with the regeneration of the $\mathrm{H}^{+}$species. By similar processes monoglycerides and glycerol will be formed. The presence of diglycerides in lipid extracts can also be seen as one of the intermediates of the reaction (Figure 9). Another grease species that was detected in thin layer chromatography was fatty esters. The formation of these components in greater quantity in the extracts of $)$ : Schmid-Bondzynski-Ratzlaff can be explained due to the presence of $\mathrm{H}^{+}$in the reaction medium by the protonation of carbonyl $(\mathrm{C}=\mathrm{O})$ present in the structure of the lipids, followed by an attack by the nucleophilic of ethanol $\left(\mathrm{CH}_{3} \mathrm{CH}_{2} \mathrm{OH}\right)$ present in the mixture of solvents used in the extraction [43] [44]. The product of this reaction is the fatty esters formed from the lipid transesterification/esterification reaction. The acidic treatment of biomass using $8 \%$ sulfuric 
acid at $160^{\circ} \mathrm{C}$ for $45 \mathrm{~min}$, for lipid extraction was reported by Halim [7] using the microalgae Chlorococcum sp. which resulted in an increase in the fatty acid content. Other studies also reported the use of an acid in the treatment of biomass resulted in an increase in the extraction process [45].

In addition, according to Figure 10, the presence of hydrochloric acid together with the polarity of the solvents: petroleum ether, ethyl ether, ethanol in the extraction process via J: Schmid-Bondzynski-Ratzlaff in both strains evaluated in this study increased extraction of unsaponifiable compounds such as sterol esters. The presence of the acid facilitated the breaking of the micro-algal cell wall and in the case of Desmodesmus sp. $10 \%$ of sterols were detected in the lipid extract via J: Schmid-Bondzynski-Ratzlaff when compared to the extract obtained via Bligh \& Dyer where this compound was not identified. Phytosterols in microalgae are found in several configurations, including free sterols, fatty acid sterol esters and glycoside sterol.

According to the literature, sterols are important constituents of cell membranes, being intertwined with phospholipid bilayers in all eukaryotes. Through this existence, sterols play significant roles in maintaining cellular structural stability and acclimatization to the membrane temperature. Sterols help maintain fluidity and permeability by controlling the movement of fatty acid chains within the membrane [46] [47]. However, it has been reported in the literature that changes in growth conditions such as: renewal rate of semi-continuous cultures [48], concentration of salt in the growth medium [49] [50] [51], type of photobioreactor [52], amount of light and phosphorus [53], temperature and silicate content [54] and growth stage of microalgae [55], can affect the production of sterols in microalgae.

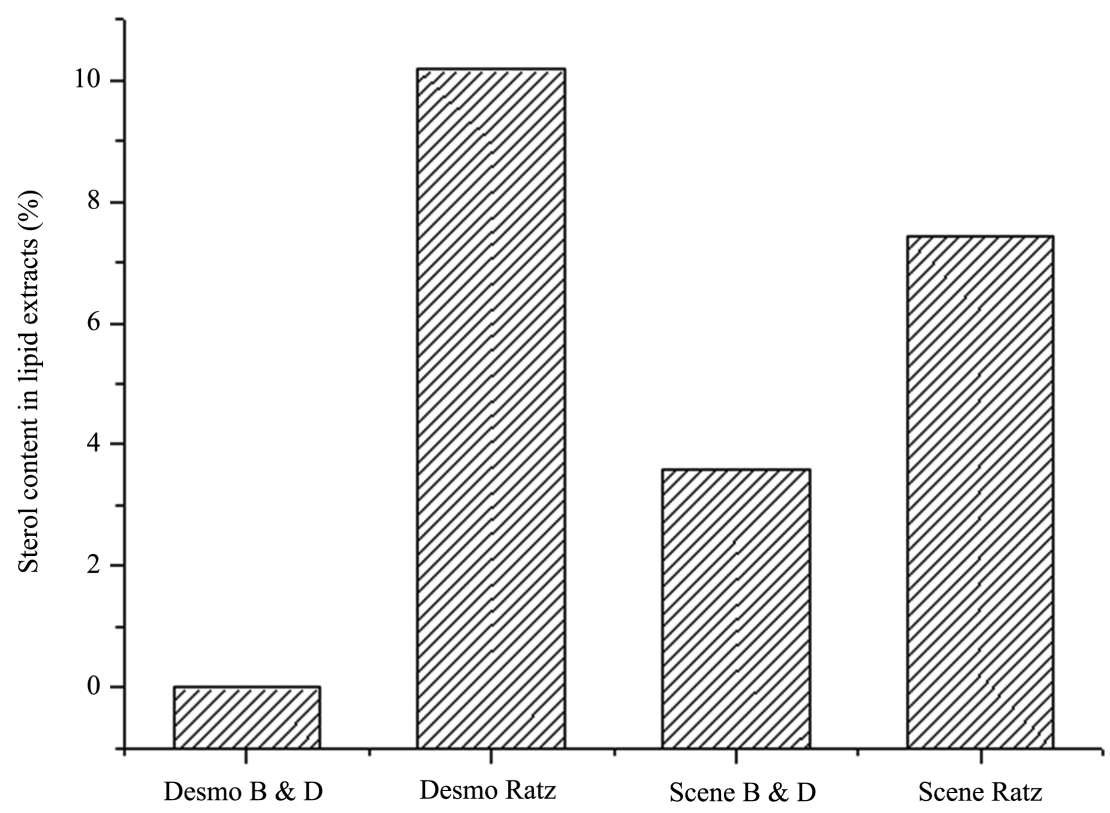

Figure 10. Sterol ester content (\%) in lipid extracts. Legend: Desmo-Desmodesmus sp.; Scene: Scenedesmus sp.; B \& D-Extraction method via Bligh and Dyer, Ratz-Extraction method via J: Schmid-Bondzynski-Ratzlaff. 
In the lipid extracts of the microalgae Desmodemus sp. and Scenedesmus sp. the presence of hydrocarbons with double conjugated bonds was detected in the same time of carotene retention in amounts of up to $2 \%$ in relation to the lipid extract. For example, during photosynthesis, microalgae absorbs sunlight, nutrients and $\mathrm{CO}_{2}$ that are converted into biomass and, at the same time, produces molecular oxygen [56] [57]. As, oxygen is easily activated by ultraviolet radiation or by the heat of sunlight transforming itself into reactive oxygen species, highly oxidizing, plants and microalgae have developed a protection mechanism against these reactive oxygen species, which consists in the production of numerous and efficient antioxidant compounds such as carotenoids.

In the Bligh \& Dyer extracts of the Desmodesmus sp. and Scenedesmus sp. biomasses, the significant presence of chlorophylls was detected in concentrations of $37.03 \%$ and $27.91 \%$, respectively (Figure 11). The use of polar solvents such as acetone, ethanol, methanol increases the affinity of these molecules with the solvent, resulting in an increase of these compounds in the extract [34]. After the acid treatment (method J: Schmid-Bondzynski-Ratzlaff), the pigments suffered a reduction of $9.18 \%$ and $7.21 \%$ of the total pigments of the Desmodesmus sp. and Scenedesmus sp. microalgae, respectively. After the addition of acid $\left(\mathrm{H}^{+}\right)$, a phenomenon occurs which is known as pheophytinization, where the magnesium in the center of the chlorophyll molecule is replaced by 2 hydrogens $\left(\mathrm{H}^{+}\right)$[58]. According to the literature, the presence of chlorophyll acts as a photosensitizer due to the production of $\mathrm{O}_{2}$ (singlet) promoting self-oxidation in vegetable oils [59]. As there is a large amount of chlorophylls, carotenoids and sterols, it was higher than that found in vegetable oils, the relative amount of triglycerides must be lower [35].

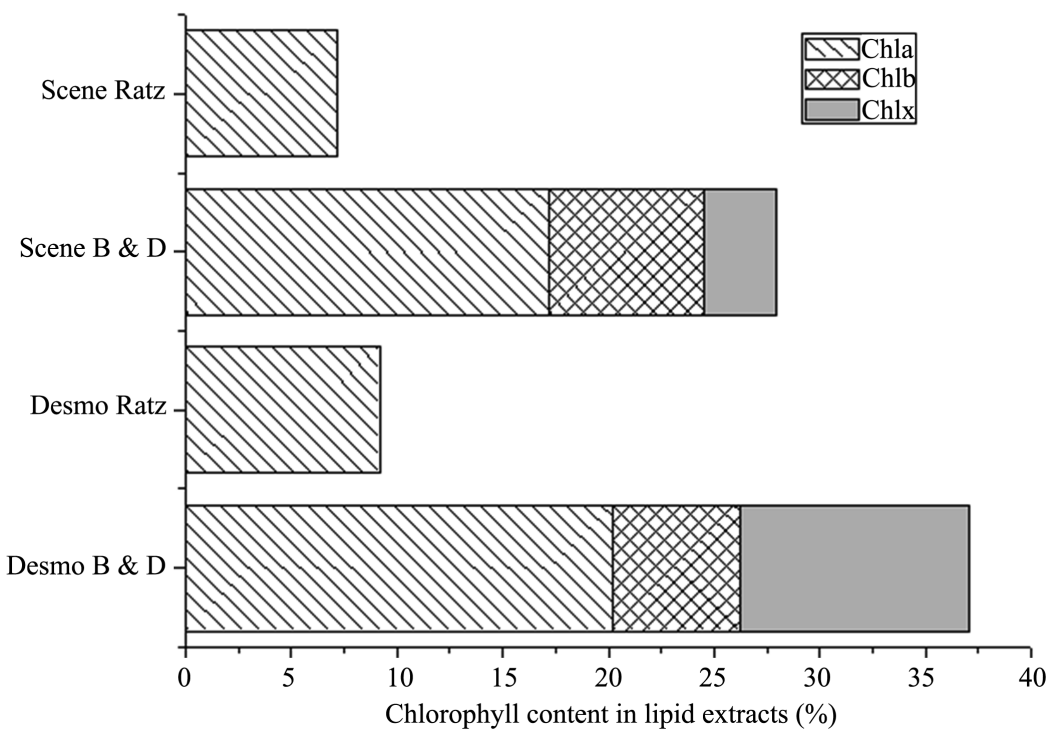

Figure 11. Chlorophyll content (\%) in lipid extracts. Legend: Chl a-Chlorophyll a; Chl b-Chlorophyll b; Chl X-Chlorophyll X (green pigment not identified). Desmo-Desmodesmus sp.; Scene: Scenedesmus sp.; B \& D-Extraction method via Bligh and Dyer, Ratz-Extraction method via J: Schmid-Bondzynski-Ratzlaff. 
After the individual analysis of the components, according to Figure 12 in this work, the amount of saponifiable and unsaponifiable material in each of the extracts was also evaluated. The components were classified as fatty the sum of the lipid components: content of fatty esters + fatty acids + triglycerides + diglycerides. As unsaponifiable, not greasy, carotenes + sterol ester + chlorophylls + polar compounds were considered. In this case, the possible conversions of the polar compounds in free fatty acids present in the extracts were neglected in order not to overestimate the results. According to Figure 12, it can be seen that acid hydrolysis contributed to the increase in fatty components of the microalgae Desmodesmus sp. and Scendesmus sp. the amount of fatty components represented $72.84 \%$ and $76.66 \%$ in relation to the total content of lipids. The amount obtained in our study was higher than that reported by Petkov [35] where the authors stated that it was possible to obtain $50 \%$ of fatty compounds after hydrolysis of the lipid extract. For the Bligh \& Dyer extracts from Desmodesmus sp. and Scendesmus sp. strains this amount was $44.74 \%$ and $50.96 \%$ of fatty components in relation to the total amount of material extracted.

From 100 grams of dry biomass of Desmodemus sp. (Bligh \& Dyer and ): Schmid-Bondzynski-Ratzlaff method) and Scenedesmus sp. (Bligh \& Dyer method) the results were statistically equal and did not exceed $4 \%$ of fatty material (Figure 13). When we evaluate only the percentage of fatty material obtained from the method of J: Schmid-Bondzynski-Ratzlaff from 100 grams of dry biomass of Scenedesmus sp. this amount was $9.55 \% \pm 0.38 \%$. Indicating that from the microalgae Scenedesmus sp. under the same growing conditions as the microalgae Desmodesmus sp. it was possible to obtain a percentage of fatty components in relation to dry weight (Figure 13).

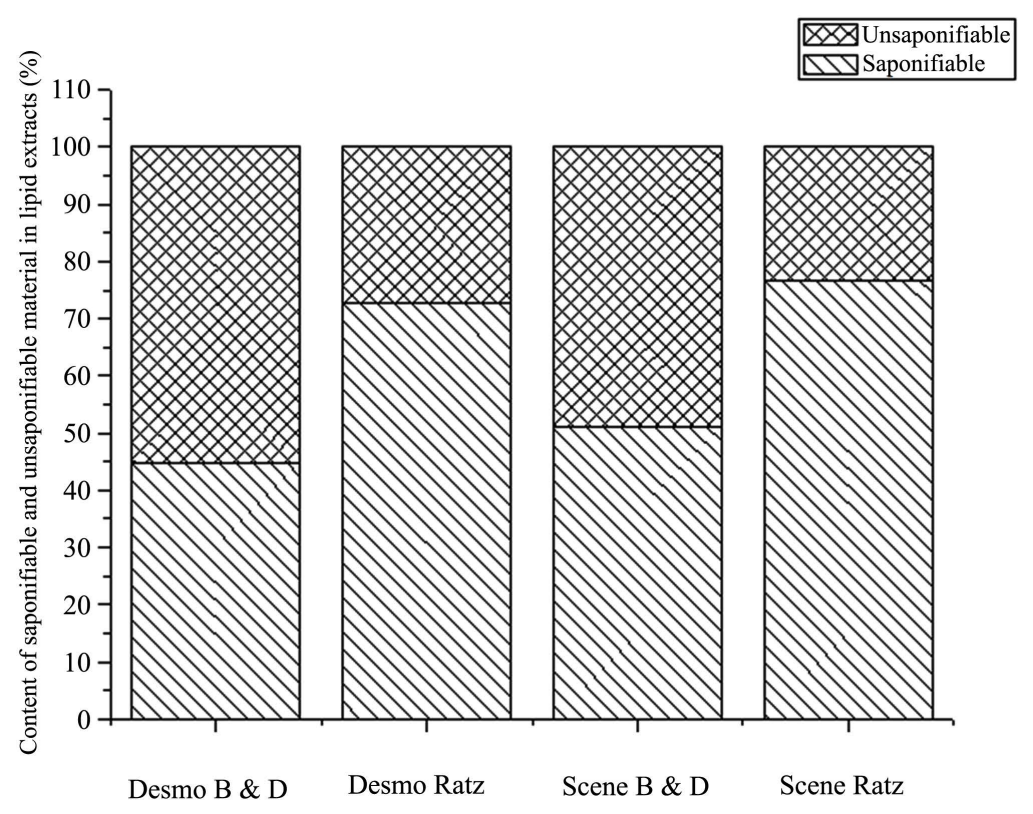

Figure 12. Saponifiable X unsaponifiable (\%) material in lipid extracts. Legend: Desmo-Desmodesmus sp.; Scene: Scenedesmus sp.; B \& D-Extraction method via Bligh and Dyer, Ratz-Extraction method via J: Schmid-Bondzynski-Ratzlaff. 


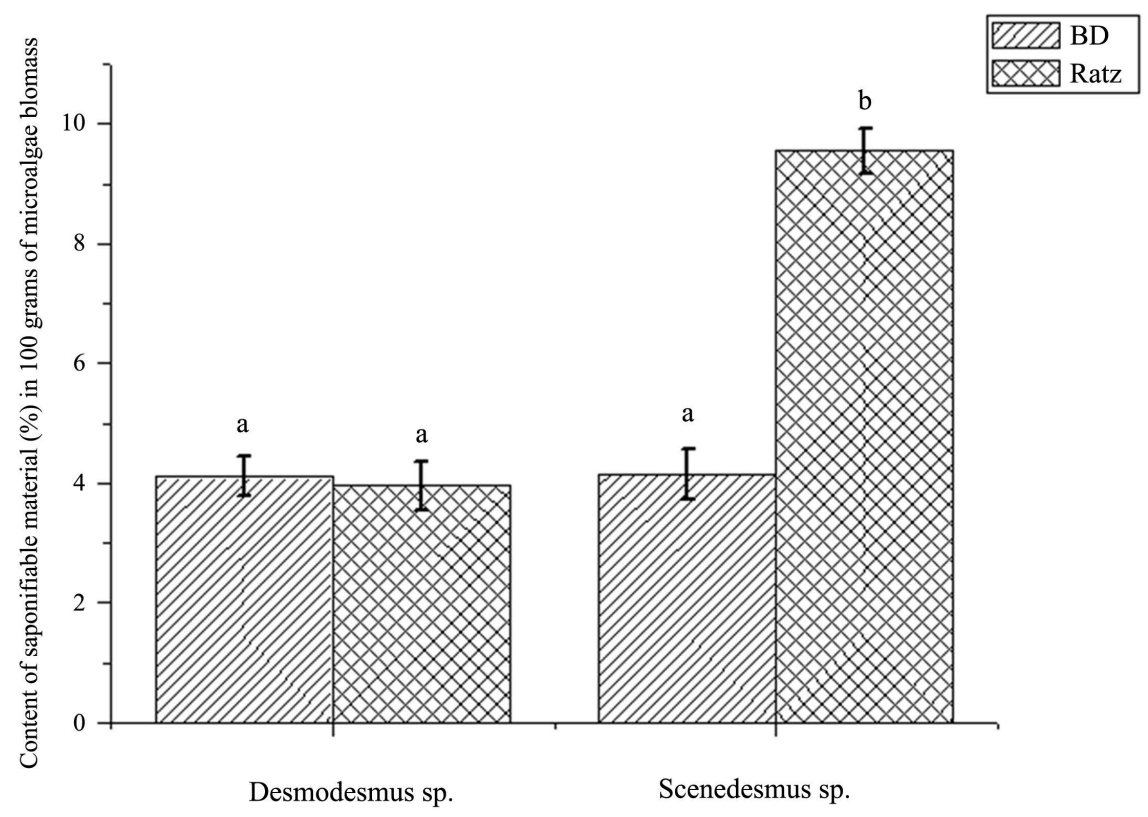

Figure 13. Content (\%) of saponifiable material* (Fatty fraction) from of Bligh \& Dyer (BD) and J: Schmid-Bondzynski-Ratzlaff (Ratz) extracts in 100 grams of dry, ash-free biomass. ${ }^{*}$ Values calculated based on triplicates of experiments from total lipid content. Different letters differ statistically from each other.

As described even after acid treatment of biomass, concentrations of other non-fatty compounds still remained in the lipid extract. Therefore, an additional step of separation and concentration of the fatty components will improve the quality of these extracts [35]. Using a purer fraction of fatty components, it will be easier to convert to biofuels, for example. The other components, such as sterols and carotenoids, can be used as high added value [60] [61] accumulation products.

\section{Conclusion}

The influence of the solvent used in the extraction and the identification of the lipid classes of the microalgae Desmodesmus sp. and Scenedesmus sp. was investigated. The content of lipids extracted with Bligh \& Dyer from the microalgae Desmodesmus sp. was $9.18 \% \pm 0.33 \%$. Whereas with the acid treatment of biomass by the method of J: Schmid-Bondzynski-Ratzlaff the microalgae Scenedesmus sp. presented $12.46 \% \pm 0.38 \%$ of lipids in relation to dry biomass. Using the Bligh \& Dyer method for extracting lipids, it was possible to verify the accumulation of triglycerides in microalgae during cultivation. The lipid extracts Desmodesmus sp. and Scenedesmus sp. extracted with Bligh \& Dyer had as main constituent the presence of approximately $25 \%$ of free fatty acids. The acid treatment made it possible to increase the amount of free fatty acids in lipid extracts by hydrolysis of complex lipids, polar compounds and triglycerides. In Bligh \& Dyer's lipid extract for Desmodesmus sp. and Scenedesmus sp. approximately $50 \%$ of the composition of this fraction consisted of fatty com- 
pounds while the other half is composed of unsaponifiable fraction, mainly chlorophylls, sterol esters and carotenes. The acid hydrolysis of the biomass of Desmodesmus sp. and Scenedesmus sp. enabled the increase to $72.84 \%$ and $76.66 \%$ of fatty material in lipid extracts. The lipid extracts showed a significant amount of unsaponifiable components that overestimated the results. Therefore, an additional step of separation and concentration of the fatty components will improve the quality of these extracts.

\section{Acknowledgements}

We thank the CENPES/Petrobras/ANP for the financial support, the GREENTEC Laboratory (UFRJ) for their support in the research, to the Federal University of Viçosa for the supply of microalgae biomass and to the financial agency (FAPERJ) for the support given.

\section{Conflicts of Interest}

The authors declare no conflicts of interest regarding the publication of this paper.

\section{References}

[1] Halim, R., Gladman, B., Danquah, M.K. and Webley, P.A. (2011) Oil Extraction from Microalgae for Biodiesel Production. Bioresource Technology, 102, 178-185. https://doi.org/10.1016/j.biortech.2010.06.136

[2] Singh, J. and Gu, S. (2010) Commercialization Potential of Microalgae for Biofuels Production. Renewable and Sustainable Energy Reviews, 14, 2596-2610. https://doi.org/10.1016/j.rser.2010.06.014

[3] Show, K., Lee, D., Tay, J., Lee, T. and Chang, J. (2015) Microalgal Drying and Cell Disruption-Recent Advances. Bioresource Technology, 184, 258-266. https://doi.org/10.1016/j.biortech.2014.10.139

[4] Borges, F.C. (2010) Proposta de um modelo conceitual de biorrefinaria com estrutura descentralizada. Tese de doutorado. Escola de Engenharia Química. Universidade Federal do Rio Grande do Sul.

[5] Borges, L., de Faria, B.M., Odebrecht, C. and Abreu, P.C. (2007) Potencial de absorção de carbono por espécies de microalgas usadas na aquicultura: Primeiros passos para o desenvolvimento de um mecanismo de desenvolvimento limpo. Atlântica, Rio Grande, 29, 35-46.

[6] Lee, J.-Y., Yoo, C., Jun, S.-Y., Ahn, C.-Y. and Oh, H.-M. (2010) Comparison of Several Methods for Effective Lipid Extraction from Microalgae. Bioresource Technology, 101, S75-S77. https://doi.org/10.1016/j.biortech.2009.03.058

[7] Halim, R., Harun, R., Danquah, M.K. and Webley, P.A. (2012) Microalgal Cell Disruption for Biofuel Development. Applied Energy, 91, 116-121. https://doi.org/10.1016/j.apenergy.2011.08.048

[8] Huerlimann, R., Nys, R. and Heimann, K. (2010) Growth, Lipid Content, Productivity, and Fatty Acid Composition of Tropical Microalgae for Scale-Up Production. Biotechnology and Bioengineering, 107, 245-257. https://doi.org/10.1002/bit.22809

[9] Wu, L.F., Chen, P.C., Huang, A.P. and Lee, C.M. (2011) The Feasibility of Biodiesel 
Production by Microalgae Using Industrial Wastewater. Bioresource Technology, 113, 14-18.

[10] Roux, J.-M., Lamotte, H. and Achard, J.-L. (2017) An Overview of Microalgae Lipid Extraction in a Biorefinery Framework. Energy Procedia, 112, 680-688. https://doi.org/10.1016/j.egypro.2017.03.1137

[11] Abomohra, A.E.-F., Eladel, H., El-Esawi, M., Wang, S., Wang, Q., He, Z.X., Feng, Y.Q., Shang, H. and Hanelt, D. (2018) Effect of Lipid-Free Microalgal Biomass and Waste Glycerol on Growth and Lipid Production of Scenedesmus obliquus: Innovative Waste Recycling for Extraordinary Lipid Production. Bioresource Technology, 249, 992-999. https://doi.org/10.1016/j.biortech.2017.10.102

[12] Sivaramakrishnan, R. and Incharoensakdi, A. (2018) Microalgae as Feedstock for Biodiesel Production under Ultrasound Treatment: A Review. Bioresource Technology, 250, 877-887. https://doi.org/10.1016/j.biortech.2017.11.095

[13] Middelberg, A.P.J. (1995) Process Scale Disruption of Microorganisms. Biotechnology Advances, 13, 491-551. https://doi.org/10.1016/0734-9750(95)02007-P

[14] Günerken, E., D’Hondt, E., Eppink, M.H.M., Garcia-Gonzalez, L., Elst, K. and Wijffels, R.H. (2015) Cell Disruption for Microalgae Biorefineries. Biotechnology Advances, 33, 243-260. https://doi.org/10.1016/j.biotechadv.2015.01.008

[15] Lee, Y., Cho, J.M., Chang, Y.K. and Oh, Y.-K. (2017) Cell Disruption and Lipid Extraction for Microalgal Biorefineries: A Review. Bioresource Technology, 244, 1317-1328. https://doi.org/10.1016/j.biortech.2017.06.038

[16] Packer, A., Li, Y.T., Andersen, T., Hu, Q., Kuang, Y. and Sommerfeld, M. (2011) Growth and Neutral Lipid Synthesis in Green Microalgae: A Mathematical Model. Bioresource Technology, 102, 111-117. https://doi.org/10.1016/j.biortech.2010.06.029

[17] Díaz, G.Ch., Cruz, Y.R., Fortes, M.M., Viegas, C.V., Carliz, R.G., Furtado, N.C. and Aranda, D.A.G. (2014) Primary Separation of Antioxidants (Unsaponifiables) the Wet Biomass Microalgae Chlamydomonas sp. and Production of the Biodiesel. Natural Science, 6, 1210-1218. https://doi.org/10.4236/ns.2014.615108

[18] Güçlü-Üstündağ, Ö. and Temelli, F. (2004) Correlating the Solubility Behavior of Minor Lipids Components in Supercritical Carbon Dioxide. Journal of Supercritical Fluids, 31, 235-253. https://doi.org/10.1016/j.supflu.2003.12.007

[19] Yao, L.X., Gerde, J.A., Lee, S.-L., Wang, T. and Harrata, K.A. (2015) Microalgae Lipid Characterization. Journal of Agricultural and Food Chemistry, 63, 1773-1787. https://doi.org/10.1021/jf5050603

[20] Clemmitt, R.H. and Chase, H.A. (2000) Immobilised Metal Affinity Chromatography of $\beta$ Galactosidase from Unclarified Escherichia coli Homogenates Using Expanded Bed Adsorption. Journal of Chromatography A, 874, 27-43. https://doi.org/10.1016/S0021-9673(00)00087-X

[21] Liu, L., Corilo, Y.E. and Marshall, A.G. (2016) Polar Lipid Composition of Biodiesel Algae Candidates Nannochloropsis oculata and Haematococcus pluvialis from Nano Liquid Chromatography Coupled with Negative Electrospray Ionization $14.5 \mathrm{~T}$ Fourier Transform Ion Cyclotron Resonance Mass Spectrometry. Energy Fuels, 30, 8270-8276. https://doi.org/10.1021/acs.energyfuels.6b01514

[22] Yap, W.B., Tey, B.T., Alitheen, N.B. and Tan, W.S. (2010) Purification of His-Tagged Hepatitis B Core Antigen from Unclarified Bacterial Homogenate Using Immobilized Metal Affinity Expanded Bed Adsorption Chromatography. Journal of Chromatography A, 1217, 3473-3480. https://doi.org/10.1016/j.chroma.2010.03.012 
[23] Álvarez-Díaz, D., Ruiz, J., Arbib, Z., Barragán, J., Garrido-Pérez, M.C. and Perales, J.A. (2015) Wastewater Treatment and Biodiesel Production by Scenedesmus obliquus in a Two-Stage Cultivation Process. Bioresource Technology, 181, 90-96. https://doi.org/10.1016/j.biortech.2015.01.018

[24] Lee, Y.-K., Chen, W., Shen, H., Han, D., Li, Y., Jones, H.D.T., TimLin, J.A. and Hu, Q. (2013) Basic Culturing and Analytical Measurement Techniques. In: Handbook of Microalgal Culture: Applied Phycology and Biotechnology, John Wiley \& Sons, Ltd., Oxford, 37-68. https://doi.org/10.1002/9781118567166.ch3

[25] Bligh, G. and Dyer, W. (1959) A Rapid Method for Total Lipid Extraction and Purification. Canadian Journal of Bio-Chemistry and Physiology, 37, 911-917. https://doi.org/10.1139/y59-099

[26] Li, Y., Naghdi, F.G., Garg, S., Adarme-Vega, T.C., Thurecht, K.J., Ghafor, W.A., Tannock, S. and Schenk, M. (2014) A Comparative Study: The Impact of Different Lipid Extraction Methods on Current Microalgal Lipid Research. Microbial Cell Factories, 13, 14. https://doi.org/10.1186/1475-2859-13-14

[27] Freitas, L.S. (2007) Desenvolvimento de procedimentos de extração do óleo de sementes de uva e caracterização química dos compostos extraídos. 227f. Tese (Doutorado em Química), Universidade Federal do Rio Grande do Sul-UFRGS, Porto Alegre.

[28] Viêgas, C.V. (2010) Extração e caracterização dos lipídeos da microalga Chlorella pyrenoidosa visando à produção de ésteres graxos. Dissertação para obtenção do título de mestre; Programa de pós-graduação em química tecnológica e ambiental, FURG, Rio Grande, RS.

[29] Zhu, F.F., Zhao, L.Y., Jiang, H.M., Zhang, Z.L., Xiong, Y.Q., Qi, J.J. and Wang, J.W. (2014) Comparison of the Lipid Content and Biodiesel Production from Municipal Sludge Using Three Extraction Methods. Energy Fuels, 28, 5277-5283.

https://doi.org/10.1021/ef500730c

[30] Schmid-Bondzynski-Ratzlaff (2012) Extração e quantificação de lipídios em microalgas. Modificado pela Universidade Federal de Viçosa. Departamento de Tecnologia de Alimentos.

[31] Mutanda, T., Ramesh, D., Karthikeyan, S., Kumari, S., Anandraj, A. and Bux, F. (2011) Bioprospecting for Hyper-Lipid Producing Microalgal Strains for Sustainable Biofuel Production. Bioresource Technology, 102, 57-70. https://doi.org/10.1016/j.biortech.2010.06.077

[32] Ramos, M.J., Fernández, C.M., Casas, A., Rodríguez, L. and Pérez, Á. (2009) Influence of Fatty Acid Composition of Raw Materials on Biodiesel Properties. Bioresource Technology, 100, 261-268. https://doi.org/10.1016/j.biortech.2008.06.039

[33] Yang, F.F., Cheng, C.H., Long, L.J., Hu, Q.J., Jia, Q.K., Wu, H.L. and Xiang, W.Z. (2015) Extracting Lipids from Several Species of Wet Microalgae Using Ethanol at Room Temperature. Energy Fuels, 29, 2380-2386. https://doi.org/10.1021/ef5023576

[34] Streit, N.M., Canterle, Hecktheuer, H., Helena, L., et al. (2005) As Clorofilas. Ciência Rural, 35, 748-755. https://www.redalyc.org/articulo.oa?id=33135343 \} https://doi.org/10.1590/S0103-84782005000300043

[35] Petkov, G., Ivanova, A., Iliev, I. and Vaseva, I. (2012) A Critical Look at the Microalgae Biodiesel. European Journal of Lipid Science and Technology, 114, 103-111. https://doi.org/10.1002/ejlt.201100234

[36] Breuer, G., Packo, L., Dirk, E.M., René, B.D. and René, H.W. (2012) The Impact of Nitrogen Starvation on the Dynamics of Triacylglycerol Accumulation in Nine Mi- 
croalgae Strains. Bioresource Technology, 124, 217-226.

https://doi.org/10.1016/j.biortech.2012.08.003

[37] Choe, E. and Min, D.B. (2006) Chemistry and Reactions of Reactive Oxygen Species in Foods. Journal of Food Science, 70, R142-R159.

https://doi.org/10.1111/j.1365-2621.2005.tb08329.x

[38] Ryckebosch, E., Muylaert, K. and Foubert, I. (2012) Optimization of an Analytical Procedure for Extraction of Lipids from Microalgae. Journal of the American Oil Chemists' Society, 89, 189-198. https://doi.org/10.1007/s11746-011-1903-Z

[39] Chen, F., Liu, J., Huang, J., Sun, Z., Zhong, Y. and Jiang, Y. (2011) Differential Lipid and Fatty Acid Profiles of Photoautotrophic and Heterotrophic Chlorella zofingiensis. Assessment of Algal Oils for Biodiesel Production. Bioresource Technology, 102, 106-110. https://doi.org/10.1016/j.biortech.2010.06.017

[40] Chew, K.W., Yap, J.Y., Show, L., Suan, N.H., Juan, J.C., Ling, T.C. and Chang, J.-S. (2017) Microalgae Biorefinery: High Value Products Perspectives. Bioresource Technology, 229, 53-62. https://doi.org/10.1016/j.biortech.2017.01.006

[41] Feng, Z., Yang, K., Xu, Z.B., Wang, Z.M., Fan, L., Qin, L. and Zhu, S.N. (2014) Growth and Lipid Accumulation Characteristics of Scenedesmus obliquus in Semi-Continuous Cultivation Outdoors for Biodiesel Feedstock Production. Bioresource Technology, 173, 406-414. https://doi.org/10.1016/j.biortech.2014.09.123

[42] Krzemińska, I., Piasecka, A., Nosalewicz, A., Simionato, D. and Wawrzykowski, J. (2015) Alterations of the Lipid Content and Fatty Acid Profile of Chlorella protothecoides under Different Light Intensities. Bioresource Technology, 196, 72-77. https://doi.org/10.1016/j.biortech.2015.07.043

[43] Martins, R.C. and Silva, C.L.M. (2002) Modelling Colour and Chlorophyll Losses of Frozen Green Beans (Phaseolus vulgaris. L.) Haricots verts congelés: Modélisation de la diminution de l'intensité de la couleur et de la teneur en chlorophylle. International Journal of Refrigeration, 25, 966-974. https://doi.org/10.1016/S0140-7007(01)00050-0

[44] Vicente, S.J.V. and Torres, E.A.F.S. (2007) Formation of Four Oxidation Products and Loss of Free Lipids, Cholesterol and Water in Beef Hamburgers as a Function of Thermal Processing. Food Control, 18, 63-68.

https://doi.org/10.1016/j.foodcont.2005.08.009

[45] Viêgas, C.V., Hachemi, I., Mäki-Arvela, , Smeds, A., Aho, A., Freitas, S.P., Da Silva, G., Mesquita, C.; Carbonetti, G., Peurla, M., Paranko, J., Kumar, N., Aranda, D.A.G. and Murzin, D.Yu. (2015) Algal Products beyond Lipids: Comprehensive Characterization of Different Products in Direct Saponification of Green Alga Chlorella sp. Algal Research-Biomass Biofuels and Bioproducts JCR, 11, 156-164.

https://doi.org/10.1016/j.algal.2015.06.014

[46] Ho, S.-H., Huang, S.-W., Chen, C.-Y., Hasunuma, T. and Kondo, A. (2013) Bioethanol Production Using Carbohydrate-Rich Microalgae Biomass as Feedstock. Bioresource Technology, 135, 191-198. https://doi.org/10.1016/j.biortech.2012.10.015

[47] Lee, O.K., Leum, A.K., Seong, D.H., Lee, C.G., Jung, Y.T., Lee, J.W. and Lee, E.Y. (2013) Chemo-Enzymatic Saccharification and Bioethanol Fermentation of Lipid-Extracted Residual Biomass of the Microalga, Dunaliella tertiolecta. Bioresource Technology, 132, 197-201. https://doi.org/10.1016/j.biortech.2013.01.007

[48] Fabregas, J., Aran, J., Morales, E.D., Lamela, T. and Otero, A. (1997) Modification of Sterol Concentration in Marine Microalgae. Phytochemistry, 46, 1189-1191. https://doi.org/10.1016/S0031-9422(97)80009-X 
[49] Francavilla, M., Trotta, and Luque, R. (2010) Phytosterols from Dunaliella tertiolecta and Dunaliella salina: A Potentially Novel Industrial Application. Bioresource Technology, 101, 4144-4150. https://doi.org/10.1016/j.biortech.2009.12.139

[50] Peeler, T.C., Stephenson, M.B., Einspahr, K.J. and Thompson Jr., G.A. (1989) Lipid Characterization of an Enriched Plasma Membrane Fraction of Dunaliella salina Grown in Media of Varying Salinity. Plant Physiology, 89, 970-976. https://doi.org/10.1104/pp.89.3.970

[51] Zelazny, A.M., Shaish, A. and Pick, U. (1995) Plasma-Membrane Sterols Are Essential for Sensing Osmotic Changes in the Halotolerant Alga Dunaliella. Plant Physiology, 109, 1395-1403. https://doi.org/10.1104/pp.109.4.1395

[52] Ponis, E., Parisi, G., Le Coz, J.R., Robert, R., Zittelli, G.C. and Tredici, M.R. (2006) Effect of the Culture System and Culture Technique on Biochemical Characteristics of Pavlova lutheri and Its Nutritional Value for Crassostrea gigas Larvae. Aquaculture Nutrition, 12, 322-329. https://doi.org/10.1111/j.1365-2095.2006.00411.x

[53] Piepho, M., Martin-Creuzburg, D. and Wacker, A. (2010) Simultaneous Effects of Light Intensity and Phosphorus Supply on the Sterol Content of Phytoplankton. PLoS ONE, 5, e15828. https://doi.org/10.1371/journal.pone.0015828

[54] Piepho, M., Martin-Creuzburg, D. and Wacker, A. (2012) Phytoplankton Sterol Contents Vary with Temperature, Phosphorus and Silicate Supply: A Study on Three Freshwater Species. European Journal of Phycology, 47, 138-145. https://doi.org/10.1080/09670262.2012.665484

[55] Xu, Z., Yan, X., Pei, L., Luo, Q. and Xu, J. (2008) Changes in Fatty Acids and Sterols during Batch Growth of Pavlova viridis in Photobioreactor. Journal of Applied Phycology, 20, 237-243. https://doi.org/10.1007/s10811-007-9230-3

[56] Ho, S.-H., Li, -J., Liu, C.-C. and Chang, J.-S. (2013) Bioprocess Development on Microalgae-Based $\mathrm{CO}_{2}$ Fixation and Bioethanol Production Using Scenedesmus $o b-$ liquus CNW-N. Bioresource Technology, 145, 142-149. https://doi.org/10.1016/j.biortech.2013.02.119

[57] Ho, S.H., Chen, C.Y. and Chang, J.S. (2012) Effect of Light Intensity and Nitrogen Starvation on $\mathrm{CO}_{2}$ Fixation and Lipid/Carbohydrate Production of an Indigenous Microalga Scenedesmus obliquus CNW-N. Bioresource Technology, 113, 244-252. https://doi.org/10.1016/j.biortech.2011.11.133

[58] Dujardin, E., Laszlo, and Sacks, D. (1975) The Chlorophylls. An Experiment in Bio-Inorganic Chemistry. Journal of Chemical Education, 52, 742. https://doi.org/10.1021/ed052p742

[59] Gunstone, F.D. (1984) Reaction of Oxygen and Unsaturated Fatty Acids. Journal of the American Oil Chemists' Society, 61, 441-442. https://doi.org/10.1007/BF02678811

[60] Lee, O.K., Oh, Y.K. and Lee, E.Y. (2015). Bioethanol Production from Carbohydrate-Enriched Residual Biomass Obtained after Lipid Extraction of Chlorella sp. KR-1. Bioresource Technology, 196, 22-27. https://doi.org/10.1016/j.biortech.2015.07.040

[61] López, E.N., Medina, A.R., Antonio, Moreno, G. and Cerdán, L.E. (2016) Extraction of Microalgal Lipids and the Influence of Polar Lipids on Biodiesel Production by Lipase-Catalyzed Transesterification. Bioresource Technology, 216, 904-913. https://doi.org/10.1016/j.biortech.2016.06.035 